\title{
The Notable Woman in Fiction: The Afterlives of Elizabeth Barrett Browning
}

\author{
Julia Novak
}

\begin{abstract}
:
Drawing on gender-sensitive approaches to biographical fiction, this paper examines fictional representations of Elizabeth Barrett Browning, from Carola Oman's Miss Barrett's Elopement to Laura Fish's Strange Music. With a focus on their depiction of her profession, the novels are read as part of the poet's afterlife and reception history.
\end{abstract}

This work was supported by the Austrian Science Fund (FWF) under Grant T 589-G23.

"Let it be fact, one feels, or let it be fiction; the imagination will not serve under two masters simultaneously," Virginia Woolf wrote in her review essay "The New Biography." While her observation was addressed to the biographer, Woolf herself demonstrated that for the novelist it was quite permissible, as well as profitable, to mingle fact and fiction in the same work. Her biographical novella of Elizabeth Barrett Browning's cocker spaniel, Flush: A Biography, provides an imaginative account of not only the dog's experiences and perceptions but also, indirectly, those of its famous poet-owner, whom critic Marjorie Stone introduces as "England's first unequivocally major female poet" (3). Elizabeth Barrett Browning's professional achievements as well as her personal history secured her public status as a literary celebrity, which lasted, in varying forms, well beyond the nineteenth century and inspired several other biographical fictions before and after Woolf's canine biography.

Fictions about "notable" historical women abound in the twentieth and twenty-first centuries and have attained particular prominence since the 1990s, with the critical and commercial success of novels such as Michael Cunningham's The Hours and Joyce Carol Oates's Blonde. ${ }^{2}$ Their hybrid nature renders them a fascinating field of critical inquiry from a biographical angle as well as from a gender studies point of view. Adopting a gender-sensitive approach to biographical fiction, this essay will examine six novels about Elizabeth Barrett Browning and locate them in the context of the poet's reception in the twentieth and twentyfirst centuries: C. Lenanton's Miss Barrett's Elopement, Virginia Woolf's Flush, Elmira Waite's How Do I Love Thee, Constance Buel Burnett's The Silver Answer, Margaret Forster's Lady's Maid, and Laura Fish's Strange Music. Critics so far have largely overlooked some of them (notably Lenanton, Waite, and Burnett). Viewed together, the novels reveal various ways in which the figure of a "notable woman" can be employed in biographical fiction and how generic specificities are complicated by questions of gender. Moreover, a 
comparison of several novels about the same subject will also allow for some more general points to be made about the functions and narrative possibilities of the biographical novel as an "in-between" genre that has gained immense popularity.

\section{From Feminist Biography to Biographical Fiction}

In The Challenge of Feminist Biography Sara Alpern notes, "today we can say that biography, once a 'men's club,' has been radically changed by the flood of attention now paid to women's lives" (5). ${ }^{3}$ Her statement points, on the one hand, to biography's long-enduring bias toward male subjects, an imbalance that was first systematically addressed by the second wave of the feminist movement in the twentieth century. An example here is Jean Strouse's essay "Semiprivate Lives," in which the author argues, "what we know of history . . . has been largely shaped by the careers of famous men" (113), echoing Carlyle's famous dictum ${ }^{4}$ but meaning it here as a criticism. On the other hand, Alpern's statement also points to the surging interest in women's lives, beginning in the late twentieth century, in part because of the efforts of feminists to redress that imbalance by harnessing biography to the "reclaiming" of lost or marginalized women's lives. In this sense biographies have served as instruments of commemoration and canonization, extending a woman's "afterlife" by adding her to a society's cultural memory.

It was not least the genre's frequently stated "exemplary function", that made it a valuable medium for conveying the agendas of the women's movement. If biography can be said to provide guidelines, examples of how to live a good life, how to "make it" as a woman, then biographies of women fulfill a crucial purpose: they offer patterns of behavior and models of female achievement (or failure) and thus have an impact on the construction of gender identities beyond the biographee's lifespan. While some feminist critics deplored biography's obvious relation with "greatness" and fame because it had led to the gender imbalance in the genre in the first place, obscuring the experiences and achievements of women, ${ }^{6}$ feminist biographers on the whole adhered to the established model and added their share of "exemplary women" to the biographical canon.

The same is true for biographical fictions of women, which have mostly been devoted to the lives of "notable" heroines. One of the reasons for this focus on "great lives," presumably, is that in the publishing industry a famous name guarantees high sales figures. Like factual biographies, biographical fictions enact the commemorative and exemplary functions of life writing and contribute to a historical person's "afterlife," as the following discussion of fictional representations of Elizabeth Barrett Browning will demonstrate. However, while biographers are expected to adhere to the principles of truthfulness, verifiability, and objectivity, no such restrictions apply to novelists, who can change facts, shift dates, and invent dialogues, thoughts, and even characters and who can thus be said to enjoy greater freedom in representing, and appropriating, their subject. This is not to say, however, that biographical novels operate independently of biographical fact: they draw on the "facts" of a life in their accounts of the biographee, sometimes adding to and confirming, sometimes contesting, the image preserved of a subject in cultural memory.

\section{Shifting Reputations: Elizabeth Barrett Browning in the Twentieth Century}

My dear Mr. Horne, the public do not care for me enough to care at all for my biography. If you say anything of me (and I am not affected enough to pretend to wish you to be absolutely silent, if you see any occasion to speak) it must be as a writer of rhymes, and not as the heroine of a biography. (Barrett Browning, qtd. in Benson 165) 
Elizabeth Barrett Browning addressed the above comment to poet and critic Richard Horne when he was about to publicize his 1844 book about notable poets, A New Spirit of the Age, which included a chapter about Barrett Browning. ${ }^{7}$ By that time Barrett Browning's profile as a poet was "almost as high as Tennyson's and higher than Browning's," as Marjorie Stone observes: "Victorian reviews of Barrett Browning's works and her impact on other writers indicate that she was widely viewed as a major poet, in England, America and some European countries from the 1840s - well before the publication of Aurora Leigh - up to the 1890s" (Stone 4). She was admired by writers such as Oscar Wilde, George Eliot, John Ruskin, and Emily Dickinson and widely discussed for her participation in central social and political debates of her day and her radical depictions of female subjectivity. ${ }^{8}$

Ironically, Barrett Browning's assessment of public interest in her person would turn out to be quite mistaken: not long after her death, and even during her lifetime, her reputation as an influential and daring poet was gradually overshadowed by the myths building up around Elizabeth Barrett Browning the private woman. Richard Horne's book chapter may well have helped to prepare the ground for this development:

Confined entirely to her own apartment, and almost hermetically sealed, in consequence of some extremely delicate state of health, the poetess of whom we write is scarcely seen by any but her own family. But though thus separated from the world - and often, during many weeks at a time, in darkness almost equal to that of night, Miss Barrett has yet found means by extraordinary inherent energies to develop her inward nature. (Horne 134)

The image Horne evoked, by now overly familiar, of Elizabeth Barrett the mysterious recluse in her dark prison prepared the ground for the sensational elopement narrative that was to attach itself firmly to her name not long after the publication of her 1844 collection Poems and which would come to dominate her reception after her death. Her father, Edward Moulton Barrett, would not permit any of his children to marry. When Elizabeth Barrett fell in love with fellow poet Robert Browning, the two eloped to Italy in 1846. In consequence, Barrett Browning was mythologized as an ailing Victorian lady who, Rapunzel-like, was rescued from the claws of an evil sorcerer-father by a poet-knight, with whom she fled to Italy at the age of 40, had a child, and lived "happily ever after" for the remaining fifteen years of her life. ${ }^{9}$

This romanticized image of the poet was fueled by the publication in 1899 of the Browning love letters - the first edition of several. At the dawn of the new century, "Elizabeth Barrett Barrett the poet was erased, and replaced by the woman chiefly known as one man's daughter and another man's wife," as Stone dryly notes (16). Indeed, Barrett Browning inspired numerous biographies, some of whose titles (The Immortal Lovers, Dared and Done: The Marriage of Elizabeth Barrett and Robert Browning, Eine Liebe in Florenz) hint at the spirit in which she would be remembered. ${ }^{10}$

It was only with the emergence of the second-wave feminist movement in the late twentieth century that Barrett Browning's work, rather than her private life, was once again considered worthy of attention. Thus, in her biography Elizabeth Barrett Browning, rather tellingly published by the Feminist Press, Mary Jane Lupton hails the poet as a kind of protofeminist, designating her epic poem Aurora Leigh a Victorian equivalent to Kate Millett's Sexual Politics in terms of its notoriety (Lupton 85). Predictably, Lupton strives to rehabilitate Barrett Browning as a poet to be taken seriously, focusing on her work and her professional achievements in the spirit of "exemplary biography," which, as already mentioned, came to be an important mode of feminist expression. The term "work" is significant here because Elizabeth Barrett Browning herself regarded poetry as her profession. In the preface to her 1844 Poems she wrote, "Poetry has been as serious a thing to me as life 
itself; and life has been a very serious thing. . . I never mistook pleasure for the final cause of poetry; nor leisure, for the hour of the poet. I have done my work, so far, as work . . . and as work I offer it to the public" (qtd. in Avery 3). A woman's public work has long formed a central focus of feminist interventions in life writing and in feminism's critique of the traditional relegation of women to the private sphere. The representation of work, in the sense of professional cultural production, will therefore also feature prominently in this essay.

In the following discussion, analyses of biographical novels about Elizabeth Barrett Browning are preceded by a discussion of Rudolf Besier's play The Barretts of Wimpole Street, not because it was the first biofiction ${ }^{11}$ of the poet's life but because it proved to have a lasting effect on her reception and afterlife and inspired other fictional treatments of the poet.

\section{The Barretts of Wimpole Street: Introducing the Romance Paradigm}

Rudolph Besier's The Barretts of Wimpole Street: A Comedy in Five Acts (1930) was successfully staged in the UK and the US and was subsequently adapted into a film in 1934 (starring Norma Shearer) and again in 1957 (with Jennifer Jones), both directed by Sidney Franklin. The blurb on the book cover sets the scene for the reader:

Elizabeth is the delicate lady, lying behind eternally closed windows, her room a sanctuary in a house of terror. Ill and lacking the will to strength, she lies looking up at the busts of Chaucer and Homer. Browning is the life-giver, the mender of a broken will, the impetuous knight who will rescue Elizabeth from her Victorian prison. (Besier)

Neither Barrett Browning's poetry nor the act of writing features at all in the play; it contains only a cursory reference to the fact that she happens to be a poet. Mr. Barrett is depicted as a possessive domestic tyrant who lets no opportunity slip to make his whole family miserable. Early on in the play, her sister Henrietta complains to Elizabeth about the unjust treatment they receive at the hands of Edward Barrett:

HENRIETTA: . . $\mathrm{Ba}^{12}$ dear, is there anything — anything at all— to be said for Papa's attitude towards marriage? Can it possibly be wrong to want a man's love desperately — and — and to long for babies of my own?

ELIZABETH: No. . . . But who am I to answer a question like that? Love and babies are so utterly remote from my life. ... (57)

Significantly, this passage constitutes an instance of dramatic irony that we may assume is deliberate, arising not from any information given in the play but from Elizabeth Barrett Browning's iconic status as one half of a legendary couple who lived one of the most spectacular romances in English literary history. At this point the play thus creates tension and expectation by drawing on the audience's prior knowledge of the poet's biography. The fact that the Brownings' courtship narrative has gained such a strong hold on public consciousness and eventually entered cultural memory arguably rests on the Brownings' public status as eminent Victorian poets. Thus, while the biographical subjects' profession must be considered crucial to the success of Besier's play, lending it a titillating celebrity factor, the text displays no interest in Barrett Browning the writer or her poetry.

Romance, then, can be said to be the dominant generic model underlying the play. Accordingly, Besier's Robert Browning is described as "wonderfully handsome" (19), and again, "the handsomest poet in England" (85). The play departs from common notions of biography as "catching a likeness" (Lee 3), and there is no mention either of the fact that 
Robert is six years Elizabeth's junior. He is strong and determined-a true romantic hero of "high alpha traits" (Roach 9) - virile, rapturous, and persistent, repeatedly telling her what to do until she finally finds the strength to commit to their common future and turn her back on her tyrannical father. "If your weakness asks my strength for support, my abundant strength cries out for your weakness to complete my life and myself," Besier's Browning cries out after declaring his undying love (105). The play thus trades in what Stone terms a "poetics of rescue" (3). It ends on the couple's elopement, which is again typical of romantic fiction: after a series of tribulations and obstacles that must be overcome, the romantic couple is triumphantly united in love. The beginning of this union forms the end point of the narrative: the obligatory Happily Ever After promise of romantic fiction.

As biography, The Barretts of Wimpole Street draws on a model of female identity that depicts Barrett Browning as an entirely relational creature, defined through, and dependent on, first her possessive father and later, increasingly, her "life-giving" bridegroom. Besier's romanticized treatment of Barrett Browning's life seems somewhat ironic when we consider her earlier reputation and self-image as a poet. Much of Barrett Browning's work set out to refute common assumptions about the role of the woman poet and her "proper sphere," transcending traditional notions of appropriately "feminine" subjects such as love (Avery 4). In his critical assessment of the impact of Besier's play on the poet's image and its distortion of historical facts, Simon Avery notes,

Barrett Browning the writer of combative and demanding works which were often condemned for their polemical politics in the nineteenth century . . . was effectively eradicated and replaced by Barrett Browning the writer of that (in)famous first line from Sonnet 43 of Sonnets from the Portuguese: 'How do I Love thee? Let me count the ways.' Endlessly mediated through Valentine cards and romantic comedies on stage and screen throughout the twentieth century, these ten words quickly became something of a metonym for Barrett Browning's complete ouvre and still remain her most famous to date, keeping the poet both firmly rooted within the romantic framework and subordinated to her husband. (12)

Avery sees The Barretts of Wimpole Street as a decisive factor in the construction of Barrett Browning's posthumous profile as a writer. Having provoked critics as a woman writer of antislavery and anti-child labor poems and having challenged Victorian notions of ideal femininity in Aurora Leigh, Barrett Browning became known chiefly as a writer of love poetry and, above all, as the heroine of a romantic elopement narrative, relegated in both ways to a genre that has always been considered distinctly feminine.

Lupton similarly condemns Besier's romance and its distorting impact on the poet's afterlife, pointing out that the play “emphasizes Elizabeth's weak body and virtually ignores her strong mind. . . . For the most part Besier's characterization centers on her feminine fragility. ... The unresisting Elizabeth of Besier's imagination is, unfortunately, the Elizabeth whom most of us know" (92). It is interesting to see that both Avery and Lupton accord Besier's bioplay considerable influence on the manner in which Barrett Browning was to survive in cultural memory, which provides some indication of the decisive role of fictionalized representations in posthumous image construction.

The popularity of The Barretts of Wimpole Street, considerably multiplied by the two film adaptations, paved the way for other popular renderings of the Brownings' life story in narrative fiction as well as on stage and television. In 1935 Wilbur Braun published his threeact comedy After Wimpole Street as a sequel to Besier's play; 1940 saw the publication of Marjorie Carleton's The Barretts: A Comedy in Three Acts, followed by Betty Quin's Romantic Journey: A Play About Elizabeth Barrett Browning in 1958; the musical Robert and 
Elizabeth came out in 1967 (with the tagline "A new musical from an original idea by Fred G. Moritt, based on The Barretts of Wimpole Street by Rudolph Besier"). In 1970 Barbara Cartland, queen of Victorian-era romance, published her novella The Perfect Romance of Elizabeth and Robert Browning; and in 1982 the BBC launched a TV series named after Besier's play, The Barretts of Wimpole Street (dir. Michael Darlow). ${ }^{13}$

Avery's and Lupton's assessments of Besier's misrepresentation can be seen to echo Carolyn Heilbrun's claim in her study Writing a Woman's Life that "accomplished women ... . live in a storyless time and are either trapped in, or have wasted energy opposing, the only narrative available to them: the conventional marriage or erotic plot" (48). What Heilbrun deplores here is the seeming absence of metanarratives that accommodate the professional achievement of women. If romance is to be the dominant model for the telling of a woman's life, it is a model that prescribes a focus on her private, emotional world, whose center is firmly occupied by a man - a preoccupation that sidelines or ignores her professional side. As will be shown, Besier's approach continued to inform other biographical fictions about Elizabeth Barrett Browning, but it was not the first fictionalization of Barrett Browning's life that drew on the myth of the poets' romance.

\section{Miss Barrett's Elopement, by C. Lenanton}

The earliest biographical novel about Barrett Browning precedes Besier's play by only a few months. Carola Oman, who wrote under the pseudonym C. Lenanton, published Miss Barrett's Elopement in 1929. Her novel demonstrates, as do the Barrett Browning biofictions from the 1950s, that the rise in fascination with the Victorians in the late twentieth century is, in fact, less dramatic than neo-Victorian scholarship seems to suggest. ${ }^{14}$

In Lenanton's novel Barrett Browning is once again depicted as "sadly delicatelooking, so very frail. It seemed a puff of wind must blow her away. . . . A tea-rose plucked for a crystal vase in a darkened room" (15) and a "timid, fluttering creature" on her brother's arm (18). Interestingly, while the title creates expectations of an insipid, breathless tale of the love-conquers-all variety, Oman's novel does in fact leave considerable room for Barrett Browning's professional life, especially in the first half. It begins with the Barretts' move in 1832 from Hope End to Sidmouth, and Robert Browning doesn't appear until halfway into the novel. It mentions the texts she was working on at various stages of her life, occasionally quoting from poems and dwelling also on the critical success she achieved. When, for example, John Kenyon, a distant relative and confidant of Elizabeth Barrett, meets author Anna Jameson at Wimpole Street, Kenyon asks his acquaintance, "Tell me. Which of her pieces in the last volume - the volume which has established her reputation, bless her! — was your favourite?" (157) When Jameson decides on "The Cry of the Children" (published in Poems, 1844), Kenyon enthuses,

"Well, it has certainly created a stir. And I believe it has done good too. There was talk of a quotation having been made from it in the House, but that, I daresay, was an exaggeration."

"Mr. Kenyon," interrupted his companion with flashing orbs, "that was a poem with a message!" (158)

Mrs. Jameson then begins to recite the poem:

"Do ye hear the children weeping, $O$, my brothers,

Ere the sorrow comes with years?

They are leaning their young heads against their mothers-

And that cannot stop their tears." 
Mr. Kenyon grew nervous again. He knew "The Cry of the Children" well. It was running through London like a wildfire this winter. In a general way he admired it, but it contained a hundred and fifty-six lines, and he had ordered a soufflé this evening. (158)

The above passage provides an example not only of the way the novel weaves references to Elizabeth Barrett's work into its narrative, approvingly though somewhat clumsily, but also of the gay, lighthearted tone that Lenanton chose for the telling of her subject's life.

Notwithstanding the "professional regard" the novel displays, Miss Barrett's Elopement ends, as the title indicates, in the carriage that is to speed the Brownings away to Dover:

With his left arm he encircled her, and with his right he raised to his lips the hand on which he had replaced the new wedding ring. Her head was on his breast and she raised her face to his.

"How do you feel, love?"

"Beautiful!” (368)

The novel thus dramatizes in its first half the years that saw Barrett Browning's professional growth and made her reputation as a poet, while its second half is devoted to the Browning love story, culminating in the famous elopement. It omits the last fifteen years of the poet's life - a phase in which many major publications such as Aurora Leigh and Poems Before Congress appeared. In what constitutes a strange clash of genres, Lenanton's biographical novel commemorates the poet's development and achievement, as any literary biography would, only to break off the narrative at the conventional Happily Ever After point of romantic fiction.

This generic mix goes some way toward explaining why reviews of the book read as though they were treating two entirely different narratives, depending on which mode the respective critic responded to. For George Currie, for instance, Lenanton's novel is "so gorgeously romantic and giddily exquisite a looking back into one of the great courtships of literature" (27) that he wishes to promote it as a linguistic model to correct the pitiful state of amorous rhetoric in his day. He seems interested only in the romantic elements of the book, which also emerges from his final assessment of the Brownings' historical significance and the author's achievement: "The Brownings are rapidly becoming as legendary as Heloise and Abelard and it may be that the time will come when neither is read, but both are affectionately remembered by a world starved for romance. . . . Mrs. Lenanton has done well by their memory" (27). This reading of the novel as romance, which apparently ignores the first half of the book in which Robert Browning has neither made an appearance nor even been mentioned, is suggested also by the cover of its Grosset \& Dunlap edition. The image features a beautiful, blue-eyed Miss Barrett, whose head is trustingly inclined on her lover's breasthe dashingly handsome, towering over her protectively, with a stern, determined, heroic look on his face.

Oscar W. Firkins's review, by contrast, is primarily interested in Lenanton's failedas he considers it-representation of the poet Barrett Browning. A professor of English at the University of Minnesota and notable poetry critic, he objects to the "gay, bluff, romping, buxom, bumptious air" (918) of Lenanton's prose, which leads to a superficial treatment, if not misrepresentation, of Barrett Browning's poetic achievement: "Mrs. Lenanton likes ever so many people; she even tolerates Elizabeth Barrett, that poor quivering, simpering, fluttering little thing, whom Fame, in a world full of bustling and jovial persons, singled out for some unguessable reason to make a pet of. Mrs. Lenanton's interest in Miss Barrett is the interest of a cabman in his 'fare"' (918). Miss Barrett's Elopement demonstrates the ease with 
which a biographical novel can participate in another subgenre of fiction: in this case, the historical romance novel. As such, the book may appeal to romance readers as well as to those with an interest in a famous poet's life and work. It reveals, moreover, that biographical fiction can, and frequently does, provoke responses on two entirely different levels of text, depending on whether it is read primarily as biography or fiction.

\section{Flush: A Biography, by Virginia Woolf}

1933 saw the publication of Virginia Woolf's Flush: A Biography, her famous imaginative biography of Elizabeth Barrett Browning's cocker spaniel. In a letter to Helen McAfee in July 1931, Woolf had briefly commented on her experience of seeing Besier's The Barretts of Wimpole Street in the theater, declaring herself "rather disappointed, though amused by the astonishing story" (Letters IV: 351). ${ }^{15}$ The play includes a short exchange during which cousin Bella comments on Mr. Browning's frequent visits to Wimpole Street, wondering "Oh, wouldn't it be fwightfully intewesting if only dear Flush could speak!" (85). It would not be too far-fetched, therefore, to assume that Woolf's new project was on some level a response to Besier's earlier fictionalization of the Brownings.

While its protagonist ostensibly is a dog, critics generally agree that Flush constitutes a fictional biography with two subjects, ${ }^{16}$ simultaneously providing a view of Elizabeth Barrett Browning "from below," so to speak. "Naturally, it is the poets we are most interested in," Hilary Newman notes (37), pointing to the convenient overlap between the dog's lifespan and the dramatic years of the Brownings' courtship and elopement, but also to the alienating effect the nonhuman point of view has on the presentation of the poets (37) - an effect, one may argue, that is permissible only in fiction.

Flush is written in the third person, the dog serving as a reflector character whose consciousness mostly determines the narrative perspective:

Then what a variety of smells interwoven in subtlest combination thrilled his nostrils; strong smells of earth, sweet smells of flowers; nameless smells of leaf and bramble; sour smells as they crossed the road; pungent smells as they entered bean-fields. But suddenly down the wind came tearing a smell sharper, stronger, more lacerating than any-a smell that ripped across his brain stirring a thousand instincts, releasing a million memories - the smell of hare, the smell of fox. (13)

Notwithstanding its use of free indirect discourse - a mode of consciousness presentation typical of modernist fiction-Flush follows many of the conventions of biography, treatingwith some irony - the dog's genealogy, recounting his life chronologically, and drawing on and acknowledging sources such as letters, in the process making these generic conventions visible in the first place through Woolf's unusual choice of a subject. Critics have consequently classified Flush as a subversive "metabiographical" exploration of the genre (Herman 547), part of Woolf's ongoing self-reflexive engagement with biographical form —or "biografiction," to use Max Saunders's term (467). ${ }^{17}$

Woolf's subversion of generic conventions in Flush has frequently also been read as entailing a feminist critique of biography's neglect of women's lives and of Victorian patriarchy in general. Thus, for Susan Squier the dog functions "as a stand-in for the woman writer" (124), representing "the marginalization and oppression of Barrett (and, by implication, of all women)" (125). ${ }^{18}$ Such a reading is supported by the overt parallels that Woolf draws between the dog and its owner, both of whom are shown to be oppressed in the Barrett household: 
For the first time she looked him in the face. For the first time Flush looked at the lady lying on the sofa.

Each was surprised. Heavy curls hung down on either side of Miss Barrett's face; large bright eyes shone out; a large mouth smiled. Heavy ears hung down on either side of Flush's face; his eyes, too, were large and bright: his mouth was wide. There was a likeness between them. (20)

More broadly, Flush has been understood as a critique of biography's preference for the "great" and "famous" (e.g., Reynier 191), an idea that Woolf frequently uttered in other contexts, as for instance in her essay "The Art of Biography": "the question now inevitably asks itself, whether the lives of great men only should be recorded. Is not anyone who has lived a life, and left a record of that life, worthy of biography - the failures as well as the successes, the humble as well as the illustrious? And what is greatness?" (125) Pamela L. Caughie reads Flush as "a testimony to the lives that have never been narrated, the inscrutable and therefore unrepresentable" (61); Saunders similarly sees the dog's perspective as a means to "unfound hierarchies of class and gender" (442) that biography frequently reflects. ${ }^{19}$

It must not be forgotten, however, that Flush's cosubject is a person of considerable fame, "no other than England's foremost poetess, the brilliant, the doomed, the adored Elizabeth Barrett herself," as Woolf introduces her reverently in Flush (15). With reference to the initial question of this essay-what the various fictions make of Barrett Browning's professional side - it is significant to note that Woolf's reverence for Barrett Browning is reflected also in her other writings on the Victorian poet. For example, in her essay on Barrett Browning's immensely successful verse novel Aurora Leigh, Woolf praises her "ardour and abundance, her brilliant descriptive powers, her shrewd and caustic humour," wondering "why it has left no successors" ("Aurora" 213). Setting Barrett Browning up as an undervalued writer in the twentieth century, Woolf attributes part of this perceived lack of interest in the poet's work to a general preoccupation with her biography ("Poet's" 101). It seems somewhat surprising, then, that Flush constitutes yet another retelling of the Browning love story that more or less ignores Barrett Browning's work. It contains only two references to her poetry: one brief mention of Aurora Leigh (Flush 63) that explains the effect of the poet's encounter with Flush's abductors on the conception of specific passages in her verse novel and Barrett Browning's sonnet about her dog, "Flush or Faunus," in its entirety at the very end (102).

Now it could be argued, of course, that the nonhuman perspective can easily be employed to relate the poet's emotional development during the Brownings' courtship, but that it is, for obvious reasons, unsuited to a treatment of Barrett Browning's work. When Robert Browning's first letter arrives, Flush is shown to respond with all the emotional intelligence available to his species: "But tonight the letter was not the same letter, it was a different letter. Flush saw that, even before the envelope was broken. He knew it from the way that Miss Barrett took it; turned it; looked at the vigorous, jagged writing of her name" (34). The act of writing, on the other hand, is perceived as "passing her hand over a white page with a black stick" (27), a viable description from a dog's point of view. However, the same passage continues with a quotation from a letter to Richard Horne: " Ah, my dear Mr. Horne,' she was writing. 'And then came the failure in my health . . . and then the enforced exile to Torquay . . . which gave a nightmare to my life for ever" (27). While Barrett Browning is never shown working on her poetry, she is, in fact, repeatedly depicted as an avid letter-writer, and Flush contains several such quotations from the letters. Woolf thus focuses on Barrett Browning the private woman, with all her personal tragedies and joys, rather than on Barrett Browning the poet.

Caughie speculates that at least initially, the conception of Flush had an economic dimension to it (53). She points to a letter to Vita Sackville-West from September 1931 in 
which Woolf refers to her project as "a little escapade by means of wh. I hope to stem the ruin we shall suffer from the failure of The Waves. This is the worst publishing season on record. No bookseller dares buy" (Letters IV: 380). In retelling a well-loved cultural myth, although from an unusual point of view, Woolf may thus have consciously set out to write a "popular novel," ${ }^{20}$ building on Barrett Browning's public status as a poet, her lasting fame, to ensure interest in her book. It would be wrong nevertheless to claim that Flush replicates Besier's approach. Not only do Woolf's formal inventions, her metabiographical stance and its implicit critique of cultural hierarchies, distinguish Flush from Besier's romance, but in her notes to Flush at the end of the book Woolf explicitly points to the significance of Barrett Browning's work, deplores its neglect by the public, and even makes a claim for the poet's "complicity in the development of modern poetry" (104).

\section{How Do I Love Thee? by Elmira Waite}

The 1950s saw the publication of two novels about Barrett Browning in the US. Helen Elmira Waite's How Do I Love Thee? The Story of Elizabeth Barrett Browning and Constance Buel Burnett's The Silver Answer: A Romantic Biography of Elizabeth Barrett Browning are similar in tone, both attempting to strike a balance between literary biography and romantic novel as they recount their subject's life and achievements from childhood up to her death in Italy in 1861. They both take their titles from well-known lines from Barrett Browning's famous collection of love poetry, Sonnets from the Portuguese, thus drawing attention to the novels' romantic aspects in a gesture that was probably assumed to help sales. Both novels disclose the sources on which they are based, primarily the Brownings' letters in various editions, from which they quote extensively.

Interestingly, Waite also mentions Besier's The Barretts of Wimpole Street and Lenanton's Miss Barrett's Elopement in her list of works consulted, which again goes to show the extent to which such biographical fictions may gain currency and impact further fictionalizations of a life and, by extension, the subject's posthumous image. In line with the romantic spirit of Besier's play, Waite's Robert Browning makes his first appearance in the novel's first chapter (16), when, in 1844, he meets Elizabeth Barrett's cousin John Kenyon and asks him to put him in touch with Miss Barrett, whose poetry he admires. Kenyon advises Browning to write to her:

Frail, invalid, sheltered $\mathrm{Ba}$ and vigorous, impetuous, handsome, popular manabout-town Robert, who had a reputation for obscure poetry and talked too fast and too loud - what would they ever have to say to each other?

Wholly unreasonable and unlikely, yet Mr. Kenyon had a queer, enveloping conviction that they would have a good deal to say to each other. (Waite 18)

This initial section is then succeeded by a lengthy flashback to Elizabeth Barrett's childhood and youth, mentioning her early efforts and later successes as a poet in London. The structural implications of the novel's opening are significant in that the couple's romance is foreshadowed at the very beginning, creating a kind of romantic bracket framing the poet's life.

With some uncertainty, How Do I Love Thee then wavers between romance and literary biography. At the couple's first meeting, Browning is introduced very much in the way of the virile, powerful hero of historical romance:

His voice was deep, like a low-toned bell, and the eyes which met Ba's were sea-blue. His handclasp was firmer than anyone had given Elizabeth Barrett for 
many years. Indeed, Mr. Browning was filled with more vitality and eagerness than anyone she had ever seen in Wimpole Street. (67)

Robert features again as Elizabeth's heroic rescuer and "life-giver" in Waite's rendering of their famous elopement. It comes as little surprise, therefore, when the novel declares that Barrett Browning's Sonnets from the Portuguese "were to be her greatest work" (111), the culmination of her poetic efforts, and that it is the only collection of Barrett Browning's poetry that Waite quotes from extensively.

However, on a professional level the novel also pictures a relationship between the lovers that overturns the traditional gender hierarchies implied by the romantic mode. Thus, Robert is shown to submit his poetry to Elizabeth's judgment- "He was beginning to rely on her suggestions, and he had really been anticipating her gay enthusiasm and pointed criticism" (86) - and the novel makes it clear that Barrett Browning's work is valued by the public far above that of her husband: "Her own books were best sellers in the United States, but she was far prouder of the fact that her husband's poetry was sold there-and read. In England her fame far over-shadowed his. So much so that when Wordsworth died Elizabeth Barrett Browning was proposed as his successor for poet laureate; no one breathed Robert's name at all" (Waite 197-98). Waite also devotes some pages to relating the phenomenal success of Barrett Browning's verse novel Aurora Leigh in 1856, noting that "Robert more than once found himself saying, 'Ba, I wish $I$ could have written this - it is inspired!'” (213), and cites some of the prominent names-Walter Savage Landor, George Eliot, John Ruskin - to be found among the novel's admirers.

\section{The Silver Answer, by Constance Buel Burnett}

In many respects similar to Waite's novel, Constance Burnett's The Silver Answer visibly takes pride in Barrett Browning's achievements, variously calling her "England's foremost woman poet" (82) or "major poetess" (101). The child Elizabeth is romanticized as a gifted, dreamy girl who cares about little besides poetry, writing The Battle of Marathon at the age of twelve (the historical Barrett was actually fourteen) and expecting it to make her famous. "It was easy. Words kept pouring out" (20), Burnett's narrator notes, depicting her young heroine as a very special child and evoking the romantic idea of inspired genius. Such an approach to a biographical subject projects their later achievements onto their early life, portraying them as "marked out all along by the seeds of their later greatness," as Liz Stanley has critically pointed out (9).

More than Waite's, Burnett's novel works with the familiar paradigm of "greatness" that feminist critics of biography have problematized for decades. The novel foreshadows Elizabeth's "greatness" repeatedly, defining it as the young poet's uppermost goal and making it clear that she has attained it when she is pictured at a literary dinner: "Wordsworth was present and Walter Savage Landor and other important people. Instead of feeling frightened, Elizabeth found herself completely at ease among the great, as though for the first time she breathed her native air" (Burnett 54). A letter from W. M. Thackeray in which he contritely rejects a poem Barrett Browning submitted to his Cornhill Magazine on the grounds of its inflammatory content is cited to underline the recognition of her status by her contemporaries: "It's your poem that you sent me months ago, and who am I to refuse the poems of Elizabeth Browning and set myself up as a judge over her?" (Burnett 207).

In Burnett's "Romantic Biography of Elizabeth Barrett Browning," as the novel is subtitled, the poet's greatness is, of course, not the only aspect of her life that is foreshadowed and then traced to its fulfillment. When Elizabeth is fifteen, her uncle Sam offers a prophetic warning: "'Beware of loving, when the time comes,' she heard Sam Barrett say, 'you don't do things by halves, Ba"” (27). When John Kenyon pays his first visit to the Barrett family in London, he muses, "Three captive sisters shut away from the world by a grim father. . . . If I 
were younger, I should certainly act the role of liberating prince to the smallest who is the poet" (54). The significance of such allusions lies in their activation of the reader's prior knowledge of Barrett Browning's biography and Robert Browning's familiar role as "liberating prince." Unlike in Waite's novel, Burnett's Robert Browning makes his first appearance only in the ninth of twenty-four chapters, but his figure is immediately employed in another instance of romantic foreshadowing, again drawing on what Stone terms the "poetics of rescue" (3) associated with retellings of Barrett Browning's life: "Pondering as he walked, Browning prodded his cane idly against an ice-covered stream which lay like a white ribbon at his feet. The stick crashed through the brittle coating and instantly the ripple of running water sounded a note of spring. He had broken the paralyzing grip of that stiff band of ice and released something that lived and sang" (Burnett 81). Accordingly, the Brownings' famous elopement narrative is also given ample space in The Silver Answer, featuring Robert Browning as a determined heroic rescuer ("eager, charged with energy, as though the buoyant life within was hard to repress . . . an athlete's broad strength . . . gray eyes that were friendly yet penetrating ... a confidence and power that were winning, rather than arrogant" [78]), and like Waite's novel, Burnett leads up to Barrett Browning's peaceful death in the arms of her loving husband. However, as a kind of coda, The Silver Answer includes a reference to the literary-historical and political significance of Barrett Browning's work:

Inscribed in marble, and fastened to the walls of Casa Guidi, there hangs now Italy's tribute to the woman who shared the nation's birth-pangs, and who, in a period of world-wide imperialism, dared raise the issue of international brotherhood.

HERE WROTE AND DIED

ELIZABETH BARRETT BROWNING

WHO IN HER WOMAN'S HEART UNITED

THE LEARNING OF A SCHOLAR WITH THE SPIRIT

OF A POET

AND OUT OF HER VERSES WROUGHT A BAND OF GOLD

'TWIXT ITALY AND ENGLAND

IN GRATITUDE THIS STONE IS PLACED

BY THE CITY OF FLORENCE

1861 (214)

Further, each of Burnett's chapters is headed by a quote from Barrett Browning's poetry. Like Waite's How Do I Love Thee, Burnett's The Silver Answer celebrates Barrett Browning's professional achievements, devoting many pages to her growth as a poet and the rapturous reception of Aurora Leigh as well as stressing the poet's public status as a nineteenth-century literary heavyweight. Thus, despite their reliance on the pull of a familiar romantic elopement narrative, both novels from the 1950s can be said to precede the efforts of feminist critics to rehabilitate their subject's professional standing by a decade, at a time when Barrett Browning's work - with the exception of her all-time popular Sonnets from the Portuguesehad long been sidelined as insignificant. We could speculate, therefore, whether these novels perhaps helped pave the way for the critical "resurrection" of Barrett Browning that was soon to follow.

The first comprehensive study of Elizabeth Barrett Browning's contribution to English poetry, Alethea Hayter's Mrs. Browning: A Poet's Work and Its Setting, was published in 1962, heralding the beginning of her critical recovery. Through the momentum of the secondwave feminist movement of the 1970s and 1980s and the rise of gynocriticism, Barrett Browning was subsequently resurrected as one of the figureheads of a neglected female literary tradition. A number of influential studies-notably by Angela Leighton, Helen 
Cooper, Dorothy Mermin, Glennis Stephenson, Marjory Stone, Linda M. Lewis, and Simon Avery and Rebecca Stott - and numerous essays have since appeared, documenting the international interest in and recognition of Elizabeth Barrett Browning as a major Victorian poet. ${ }^{21}$ In the following I will discuss the most recent novels about Barrett Browning, which must again be seen as responding and contributing to the poet's critical recovery.

\section{Lady's Maid, by Margaret Forster}

In 1990, following her own factual biography Elizabeth Barrett Browning, Margaret Forster published her novel Lady's Maid in obvious response to Woolf's note in Flush on Barrett Browning's personal maid: "The life of Lily Wilson is extremely obscure, and thus cries aloud for the services of a biographer" (Flush 154). Like Woolf's earlier biographical fiction, Lady's Maid offers a decentered perspective on the poet through the person of Elizabeth Wilson, who served her for some years in London, was instrumental in the Browning's elopement, and remained close to Barrett Browning in Italy until the latter died in 1861. In an interview Forster recounts that her decision to tell Wilson's life as a novel stemmed from her frustration about the dearth of material available on the servant's life: "you can't write about the servants in history because not enough is known about them" ("Maid" 11).

As in Flush, it is somewhat unclear who the true subject of Forster's novel is - the maid, whose tribulations we follow, or her mistress, who is shown to be at the center of her life. And as in Woolf's biofiction, we must suspect that the attraction of Forster's novel lies in its employment of a famous co-subject, since Wilson's story has been judged "uneventful" and "vicarious" by critics (Robbins 224). But unlike the cocker spaniel, the figure of the maid is employed to provide glimpses of Barrett Browning's work and critical discussions thereof. Forster embraces this opportunity to utter a fierce Marxist critique of Barrett Browning the private person in relation to her poetry. After Flush is stolen and recovered, for instance, Wilson is asked to feed chicken breast to the dog for a week as a treat. Having personal experience with poverty, she is indignant about Flush's costly diet, remarking to a fellow servant, "Have you read Miss Elizabeth's poem as is about poor children starving and cold? . . . It is a beautiful poem . . . but I cannot help thinking, when I read it, as I did again last night, I cannot help thinking of Flush eating breast of chicken." (71).

As I have previously noted, although Lady's Maid does recount the Browning's legendary courtship and elopement through the figure of a servant who came to play a crucial role in them, the reiteration of this famous romance is not central to its narrative (Novak and Mayer 31-36). Rather, it depicts Barrett Browning as a woman poet proud to step beyond the thematic confines of her "proper sphere," repeatedly declaring it her duty to "speak out" against social injustice, but who is revealed to underpay her maid and make life difficult for her in various other ways. Remarkably, Forster's critique of the poet is founded on her engagement with her work: she takes Barrett Browning seriously-and to task - as a writer. ${ }^{22}$

If fictional biographies, like all other biographies, can be variously placed between the two poles of hagiography and "dethroning" in their assessment of the biographee, Lady's Maid is clearly the one that is most critical of Barrett Browning, confirming Forster's often noted "commitment to speak about class" (Robbins 224). By focusing on the relationship between mistress and maid, Forster thus uses a famous life-story to convey in her novel a broader critique of Victorian social hierarchies.

\section{Strange Music, by Laura Fish}

Laura Fish's novel Strange Music, the most recent fictional treatment of Barrett Browning, sets out with a postcolonial agenda that goes well beyond the retelling of Barrett Browning's life. Leaving aside Woolf's modernist experimental treatment of the Barrett Browning myth 
through the eyes of a dog, Lady's Maid and Strange Music seem to suggest that a story that has been told and quite often retold in various forms permits new authors to depart more markedly from a "straight" telling of it. The general familiarity of readers and the public with their subject gives them more leeway to treat her as a carrier of specific ideological concerns, to emphasize traits in the protagonist's character or work that have so far been neglected, and to present a famous figure in a more critical light or in a new context that may have played no role in earlier versions. Notwithstanding these parallels between Forster's and Fish's novels, the two fictions differ profoundly in their evaluation of Barrett Browning as a writer.

Strange Music features three distinct narrative strands, two of which are written in Jamaican patois. The novel is set in England and Jamaica around 1840, at a time when slavery had been nominally abolished and replaced by an "apprenticeship system" that forced exslaves to remain on the plantations for minimum pay and which increasingly caused social and political unrest. The three narrators are Elizabeth Barrett, the creole domestic maid Kaydia, and the black fieldworker Sheba, the latter two working on the Barretts' Cinnamon Hill estate in Jamaica. These two are fictional characters, representing the plight of black women in Jamaican slave society as they find themselves abused by their white masters.

Elizabeth Barrett, who is confined to her sofa in Torquay by her chronic ill health, reaches out to them in thought. Her narrative covers her life from November 1838 to April 1840 , thus constituting the only biographical fiction about the poet that is not concerned with the courtship story. It reflects Barrett's growing awareness of her family's implication in the atrocities committed by white plantation owners.

I am an abolitionist. I belong to a family who have long been West Indian slave-holders, and if I believed in curses, I should be afraid. . . . Bro read to me of a large West Indian proprietor examined by a committee of the House of Lords who could not name any overseer, driver, or other man in authority who did not keep an African mistress. Did my father's cousin commit murder? Was the victim a child or with child? Might the children have been his? (59)

This awareness goes hand in hand with her development of an independent poetic voice: "Despite all dear Papa says, I instinctively believe a woman does have a business with questions like the questions of slavery. She should not write if she believes otherwise" (23).

Toward the end of the novel, Elizabeth Barrett begins to write her well-known abolitionist poem "The Runaway Slave at Pilgrim's Point," from which Fish took the idea for her novel. As such, Strange Music holds a special position within the series of Barrett Browning biofictions, since it was directly inspired by Barrett Browning's work - a testimony to Fish's regard for her subject's oeuvre. ${ }^{23}$ The poem sympathetically dramatizes the story of a female runaway slave who after being raped commits infanticide out of despair, a story echoed in Sheba's tale.

Like Lady's Maid, Strange Music can thus be understood as resulting from Fish's engagement with Barrett Browning's work, though it differs considerably in its assessment of the protagonist. ${ }^{24}$ It revolves in part around the genesis of a literary text and the maturation of its maker, pointing to the laudable courage and female solidarity displayed by a famous woman poet. Through the well-known figure of Barrett and her canonical text, the novel makes a point about the wrongs of imperialism and the common humanity of colonizer and colonized.

\section{Conclusion}

Comparing several biographical novels about Elizabeth Barrett Browning has revealed a number of salient features and specificities of biographical fiction as well as the great variety 
of approaches and choices open to fiction writers in their representation of the "same" life. Because of their hybrid nature, biographical novels can appeal to two very different reader interests and provoke reader responses on two different levels - as fiction or as biography. Since not only the conventions of biography but also those of fictional narration are available to authors, they may choose to tell a life through an unusual, decentered perspective and employ narrative modes typical of fiction, such as free indirect discourse, which suggests the narrator's direct access to a subject's thoughts - something considered to be atypical of "straight" biography. They can draw on fictional means such as dramatic irony but play with the reader's knowledge of a famous subject's biography in the process, activating additional layers of meaning by pointing outside the text. Further, they can participate not only in biographical subgenres such as literary biography but also in fictional subgenres such as the romantic novel, aligning their structure and character properties with its requirements.

Viewed as a series, the biofictions of Barrett Browning have also demonstrated the significance of intrageneric influence, manifest in the guise of affirmative continuationssuch as Elmira Waite's acknowledgement of Besier and Lenanton-or in a more revisionist vein, with Virginia Woolf taking her cue from Besier's The Barretts of Wimpole Street, for example, and Margaret Forster in turn responding to Flush in Lady's Maid.

Two major conclusions can be drawn about biofictional representations of the poet Elizabeth Barrett Browning specifically, the first one tending to the question what these fictions do to her-how they contribute to and shape her posthumous reputation as a woman writer - the second, what they do with the poet. First, depending on a text's treatment of Barrett Browning's work, or lack thereof, a fictional version of her life may contribute to her literary reputation, raising or maintaining interest in her oeuvre and commemorating her achievement, or remember her solely for a limited sequence of her private life as the heroine of a Victorian romance. The example of Besier's The Barretts of Wimpole Street has demonstrated the remarkable impact that fictional biographies can have on a historical person's "afterlife" - to the extent that they influence the reception of a poet's work and her position in literary history - and also that the choice between the figures of professional poet and romantic heroine is clearly a gendered choice.

Second, Barrett Browning's public status as a poet, her literary "star potential," underlies all of these texts as a "selling point" that can be used for varying purposes and to convey a number of different concerns, which confirms Joe Moran's assessment of literary celebrities as "complex cultural signifiers who are repositories for all kinds of meanings" (10). The fictions discussed have variously been shown to make a point about the generic blind spots of biography (its predilection for "famous" or "great" lives), to spin a tale of romantic rescue that would satisfy the tastes of a romance audience, to focus on Victorian class and gender hierarchies, or to comment on colonial exploitation, employing the figure of a "notable woman" as a vehicle for their literary and identity politics.

\section{Notes}

${ }^{1}$ Latham responds to this claim in her essay "Serv[ing] under Two Masters," which reviews four biographical novels about Virginia Woolf.

${ }^{2}$ This increased fascination with historical women, and especially with artists, is in fact a cross-generic phenomenon also pertaining to drama and film, as demonstrated by Agnès Merlet's motion picture Artemisia and more recent films such as Julie Taymor's blockbuster Frida, Christine Jeff's Sylvia, and Julian Jarrold's Becoming Jane. There are numerous recent plays featuring women artists, as, for example, shown by Kramer's study about dramatic reconstructions of female life-course models. 
${ }^{3}$ Alpern's notion of biography as a men's club is echoed by Marian and Ní Dhúill, who claim that the history of biography can be conceived of as a history of dominance over women (171).

4 "The history of the world is but the biography of great men" (Carlyle 26).

${ }^{5}$ In an interview, eminent British biographer Hermione Lee speaks of a "deep, almost religious passion for exemplary lives" in Anglo-American biography, even today (Lee, "Interview").

${ }^{6}$ For a critique of feminism's adherence to the premises of conventional biographical patterns, see for example Marian and Ní Dhúill's critique of Heilbrun (161). See also Reulecke.

${ }^{7}$ In fact, Elizabeth Barrett herself contributed sections to several chapters in A New Spirit of the Age, for instance the Tennyson and Carlyle essays.

${ }^{8}$ For a brief overview of Barrett Browning's reputation in the nineteenth century, see Stone and Taylor's introduction to the Broadview selected edition of Barrett Browning's poems. The authors point out, for instance, that Barrett Browning's Poems (1844) had garnered some thirty-five reviews in the year after their publication but had been virtually erased from the canon of nineteenth-century poetry by the mid-twentieth century.

${ }^{9}$ As such, the mythologizing to which Barrett Browning was subjected can be compared to the reception in popular culture of the Brontë sisters, as documented by Lucasta Miller's The Brontë Myth.

${ }^{10}$ The myth of her courtship and marriage was not, however, the only factor responsible for the decline of her image as a poet from the second half of the nineteenth century onwards. Stone and Taylor point both to the conservative political climate that emerged midcentury and entailed a backlash against the women's movement in England (40-42) and to the shift in aesthetic tastes brought about by the rise of New Criticism at the beginning of the twentieth century (4). For a discussion of the poet's critical fortunes see also chapter 5 in Stone, chapter 4 in Lootens, and Donaldson's annotated bibliography, which documents the interest the love letters attracted.

11 Martin Middeke uses the term "biofiction" to denote "fictional rewritings" (3) in both narrative fiction and drama.

${ }^{12}$ Elizabeth Barrett Browning was called "Ba" by her family and intimate acquaintances.

${ }^{13}$ See also Avery (12) for an overview of Barrett Browning biofictions in the wake of The Barretts of Wimpole Street.

14 John Kucich and Dianne F. Sadoff's seminal essay collection Victorian Afterlife: Postmodern Culture Rewrites the Nineteenth Century and Ann Heilmann and Mark Llewellyn's Neo-Victorianism: The Victorians in the Twenty-First Century, 1999-2009, for instance, study rewritings of the Victorian period as a late twentieth and twenty-first-century phenomenon.

${ }^{15}$ See also Sullivan's article "The Bestseller and the City: Flush, The Barretts of Wimpole Street, and Cultural Hierarchies" for a comparison of the two works.

${ }^{16}$ See, for instance, Reynier (189, 195); Saunders (442).

${ }^{17}$ In a letter to Ottoline Morrell in February 1933, Woolf explains that "Flush is only by way of a joke. I was so tired after the Waves, that I lay in the garden and read the Browning love letters, and the figure of the dog made me laugh so I couldn't resist making him a Life. I wanted to play a joke on Lytton - it was to parody him" (Letters V: 161-62).

${ }^{18}$ For a discussion of Woolf's experimentation with biographical forms in relation to her feminist politics, see also Lee, Virginia Woolf (13-15).

${ }^{19}$ Woolf also calls for a biography of Barrett Browning's personal maid Lily Wilson in one of her notes to Flush because (not "although") Wilson's life was "obscure" (Flush 105). See also Sullivan (117) and Herman (547) for their treatment of Woolf's subtle deconstruction of cultural hierarchies in Flush. 
The position and purpose of Flush in the context of Woolf's oeuvre have been discussed extensively. It has also been read as "an allegory of canon-formation" (Caughie 49), for instance. Other critics such as Smith have since objected to the purely "metaphorical" readings of Woolf's dog biography and pointed readers back to the nonhuman subjectivity it represents. In a similar vein, McDonell analyzes Barrett Browning's relationship to her dog on the basis of her letters, reading it as a constant negotiation of the boundaries between the human and the animal that springs from the poet's acknowledgement of "the agency and uniqueness of other species" (21).

${ }^{20}$ Flush turned out to be a popular success indeed; it was serialized in Atlantic Monthly and promoted as a Book of the Month Club selection. See Herman (548).

${ }^{21}$ For an outline of Barrett Browning's critical recovery, see also the extended headnotes to Donaldson et al.'s five-volume edition from 2010, The Works of Elizabeth Barrett Browning.

${ }^{22}$ For a more detailed analysis of Forster's authorial "dethroning" in Lady's Maid, see Novak and Mayer (31-36). It is also interesting to note that in addition to her biography of the poet, Forster published a collection of Selected Poems of Barrett Browning in 1988, thus contributing to the second-wave feminists' efforts to raise interest in Barrett Browning's work.

${ }^{23}$ See Fish's essay "Strange Music," in which she elaborates on the critical context and composition of the novel.

${ }^{24}$ For a more detailed discussion of Fish's reverence for Barrett Browning in Strange Music, see Novak and Mayer (30).

\section{References}

Alpern, Sara, ed. The Challenge of Feminist Biography: Writing the Lives of Modern American Women. Urbana: U of Illinois P, 1992. Print.

Avery, Simon. "Introduction: A Poet Lost and Regained." Elizabeth Barrett Browning. Ed. Avery and Rebecca Stott. London: Longman, 2003. 1-22. Print.

Barrett Browning, Elizabeth. The Works of Elizabeth Barrett Browning. Ed. Sandra Donaldson et al. 5 vols. London: Pickering and Chatto, 2010. Print.

Benson, Arthur Christopher. "Elizabeth Barrett Browning." Essays. Auckland: Floating Press, 2014. 165-88. Ebook.

Besier, Rudolf. The Barretts of Wimpole Street: A Comedy in Five Acts. Boston: Little, Brown, 1931. Print.

Burnett, Constance Buel. The Silver Answer: A Romantic Biography of Elizabeth Barrett Browning. New York: Knopf, 1955. Print.

Carlyle, Thomas. On Heroes, Hero-Worship, \& the Heroic in History. 1840. The Norman and Charlotte Strouse Edition of the Writings of Thomas Carlyle. Ed. Michael K. Goldberg. Berkeley: U of California P, 1993.

Caughie, Pamela L. "Flush and the Literary Canon: Oh Where Oh Where Has That Little Dog Gone?" Tulsa Studies in Women's Literature 10.1 (1991): 47-66. Print.

Cooper, Helen. Elizabeth Barrett Browning: Woman and Artist. Chapel Hill: U of North Carolina P, 1988. Print.

Currie, George. "The Sad Decline of Elegant Courting." Brooklyn Daily Eagle 12 Mar. 1930: 27. Brooklyn Newsstand. Brooklyn Public Library, n.d. Web. 24 August 2015.

Cunningham, Michael. The Hours. London: Fourth Estate, 1999. Print.

Donaldson, Sandra. Elizabeth Barrett Browning: An Annotated Bibliography of the Commentary and Criticism, 1826-1990. New York: Hall, 1993. Print. 
Firkins, Oscar W. "The Jester in the Shrine: Miss Barrett's Elopement, by C. Lenanton (Carola Oman)." The Saturday Review of Literature 12 April 1930: 918. UNZ.org. UNZ.org, n.d. Web. 24 August 2015.

Fish, Laura. Strange Music. London: Vintage, 2008. Print.

-. "Strange Music: Engaging Imaginatively with the Family of Elizabeth Barrett Browning from a Creole and Black Woman's Perspective.” Victorian Poetry 44.4 (2006): 50724. Print.

Forster, Margaret. Lady's Maid. London: Chatto \& Windus, 1990. Print.

Hayter, Alethea. Mrs. Browning: A Poet's Work and Its Setting. London: Faber and Faber, 1962. Print.

Heilbrun, Carolyn. Writing a Woman's Life. 1989. London: Women's Press, 1997. Print.

Herman, David. "Modernist Life Writing and Nonhuman Lives: Ecologies of Experience in Virginia Woolf's Flush.” Modern Fiction Studies 59.3 (2013): 547-68. Print.

Horne, Richard H. A New Spirit of the Age. London: Smith, Elder, 1844. Archive.org. Web. 15 May 2014.

Kramer, Stephanie. Fiktionale Biographien: (Re-)Visionen und (Re-)Konstruktionen weiblicher Lebensentwürfe in Dramen britischer Autorinnen seit 1970. Trier: WVT, 2000.

Kucich, John, and Dianne F. Sadoff, eds. Victorian Afterlife: Postmodern Culture Rewrites the Nineteenth Century. Minneapolis, Minn.: Univ. of Minnesota Press, 2000. Print.

Latham, Monica. "Serv[ing] under Two Masters: Virginia Woolf's Afterlives in Contemporary Biofictions." a/b: Auto/Biography Studies 27.2 (2012): 355-73. Web.

Lee, Hermione. "Biography-A 'Peculiarly British Vice'? Interview with Hermione Lee." Interview by Deborah Holmes, Caitríona Ní Dhúill, and Hannes Schweiger. Ludwig Boltzmann Institute for the History and Theory of Biography, Vienna. 21 April 2006. Web. 12 Jan 2014.

-. Biography: A Very Short Introduction. Oxford: Oxford UP, 2009. Print.

—. Virginia Woolf. London: Vintage, 1997. Print.

Leighton, Angela. Elizabeth Barrett Browning. Brighton: Harvester, 1986. Print.

Lenanton, C. [Carola Oman]. Miss Barrett's Elopement. London: Hodder and Stoughton, 1929. Print.

Lewis, Linda M. Elizabeth Barrett Browning's Spiritual Progress: Face to Face with God. Columbia: U of Missouri P, 1998. Print.

Lootens, Tricia A. Lost Saints: Silence, Gender, and Victorian Literary Canonization. Charlottesville: U of Virginia P, 1996. Print.

Lupton, Mary Jane. Elizabeth Barrett Browning. Old Westbury: Feminist Press, 1972. Print.

"Maid: Story Gives a Different View of Victorian Times." Herald 7 Sept. 1990, weekend ed.: 11. LexisNexis. Web. 5 March 2013.

Marian, Esther, and Caitríona Ní Dhúill. "Ein 'männliches Genre'? Bericht vom GenderArbeitskreis des Ludwig Boltzmann Instituts für Geschichte und Theorie der Biographie." Ludwig Boltzmann Institut für Geschichte und Theorie der Biographie. Ludwig Boltzmann Institut für Geschichte und Theorie der Biographie, 2008. 22 Nov 2010. Web.

McDonell, Jennifer. "Ladies Pets' and the Politics of Affect: Elizabeth Barrett Browning and Flush." Australian Literary Studies. 23.1 (2010): 17-34.

Mermin, Dorothy. Elizabeth Barrett Browning: The Origins of a New Poetry. Chicago: U of Chicago P, 1989. Print.

Middeke, Martin. "Introduction." Biofictions: The Rewriting of Romantic Lives in Contemporary Fiction and Drama. Ed. Martin Middeke \& Werner Huber. Rochester, N.Y.: Camden House, 1999. 1-25. Print.

Miller, Lucasta. The Brontë Myth. London: Vintage, 2002. Print. 
Moran, Joe. Star Authors: Literary Celebrity in America. London: Pluto, 2000. Print.

Newman, Hilary. "Flush as an Example of Virginia Woolf's Art of Biography." Virginia Woolf Bulletin 27 (2008): 30-37. Print.

Novak, Julia, and Sandra Mayer. "Disparate Images: Literary Heroism and the "Work vs. Life' Topos in Contemporary Biofictions about Victorian Authors." Neo-Victorian Studies 7.1 (2014): 25-51. Web.

Oates, Joyce Carol. Blonde: A Novel. London: Fourth Estate, 2000. Print.

Reulecke, Anne-Kathrin. “'Die Nase der Lady Hester': Überlegungen zum Verhältnis von Biographie und Geschlechterdifferenz." Biographie als Geschichte. Ed. Hedwig Röckelein. Tübingen: Ed. Diskord, 1993. 117-42. Print.

Reynier, Christine. "The Impure Art of Biography: Virginia Woolf's Flush." Mapping the Self: Space, Identity, Discourse in British Auto/Biography. Ed. Frédéric Regard. SaintÉtienne: Publ. de. L’Univ. de Saint-Étienne, 2003. Print.

Robbins, Ruth. "Hidden Lives and Ladies' Maids: Margaret Forster's Elizabeth Barrett Brownings." Women: A Cultural Review 15.2 (2004): 217-29. Print.

Saunders, Max. Self Impression: Life-Writing, Autobiografiction, and the Forms of Modern Literature. Oxford: Oxford UP, 2010. Print.

Smith, Craig. "Across the Widest Gulf: Nonhuman Subjectivity in Virginia Woolf's Flush." Twentieth Century Literature 48.3 (2002): 348-61. Print.

Squier, Susan M. Virginia Woolf and London: The Sexual Politics of the City. Chapel Hill: U of North Carolina P, 1985. Print.

Stanley, Liz. The Auto/Biographical I: The Theory and Practice of Feminist Auto/Biography. Manchester: Manchester UP, 1992. Print.

Stephenson, Glennis. Elizabeth Barrett Browning and the Poetry of Love. Ann Arbor: UMI Research Press, 1989. Print.

Stone, Marjorie. Elizabeth Barrett Browning. Basingstoke: Macmillan, 1995. Print.

Stone, Marjorie, and Beverly Taylor. Introduction. Elizabeth Barrett Browning: Selected Poems. Ed. Stone and Taylor. Peterborough, ON: Broadview, 2009. 1-48. Print.

Strouse, Jean. "Semiprivate Lives." Studies in Biography. Ed. Daniel Aaron. Cambridge: Harvard UP, 1978. 113-29. Print.

Sullivan, Melissa. "The Bestseller and the City: Flush, The Barretts of Wimpole Street, and Cultural Hierarchies." Selected Papers from the Annual Conference on Virginia Woolf 19 (2010): 112-19. Print.

Waite, Elmira. How Do I Love Thee? The Story of Elizabeth Barrett Browning. Philadelphia: The Junior Literary Guild; Macrae Smith Company, 1953. Print.

Woolf, Virginia. "The Art of Biography." The Death of the Moth and Other Essays. London: Hogarth, 1981. 119-26. Print.

—. "Aurora Leigh.” The Common Reader: Second Series. London: Hogarth, 1948. 202-13. Print.

—. Flush: A Biography. 1933. Harmondsworth: Penguin, 1981. Print.

—. The Letters of Virginia Woolf. Vol. IV. 1929-1931. Ed. Nigel Nicolson. London: Hogarth, 1978. Print.

- The Letters of Virginia Woolf. Vol. V. 1932-1935. Ed. Nigel Nicolson. London: Hogarth, 1979. Print.

—. "The New Biography." 1927. Collected Essays. Vol. IV. London: The Hogarth Press, 1967. 229-35. Print.

—. "Poets' Letters." The Essays of Virginia Woolf. Vol. 1. Ed. Andrew McNeillie. London: Hogarth, 1986. 101-05. Print. 
Biographical note:

Julia Novak is a Hertha Firnberg Research Fellow (Austrian Science Fund) and lecturer at the Department of English, University of Salzburg, where she is working on a postdoc project on fictional biographies about historical women artists. She has written a book on reading groups, Gemeinsam Lesen (Lit 2007), and a book entitled Live Poetry: An Integrated Approach to Poetry in Performance (Rodopi 2011). Her edited and coedited books include Staging Interculturality (WVT 2010) and Ireland in/and Europe (WVT 2012). 